\title{
Advance Praise for Blockchain, Fintech, and Islamic Finance
}

The authors are to be congratulated for this book. It is an important pioneering effort. The work is on the frontier of knowledge in the new area of Fintech. As is well known, the financial sector is suffering from low levels of trust in a trust-intensive industry. Islamic finance too is facing a low-trust environment that has denied it the use of the strongest of its characteristics: risk-sharing. As a result, it has resorted to debt-based financing. Blockchain/ smart contracts provide potentially powerful tools to address the low-trust challenge. The authors have done a great service to Islamic and conventional finance by producing a book that should be read by anyone interested in finance and economics.

- Prof. Dr. Abbas Mirakhor, Holder of the First Chair of Islamic Finance at

INCEIF; retired Dean of the Executive Board of the International Monetary Fund (IMF), Washington D.C.

This is an important contribution by the authors to two emerging fieldsIslamic finance and FinTech. In this respect, it touches two frontiers as this research could pave the way for the development of both fields. FinTech offers great potential for reaping the benefits of Islamic finance and this book provides an excellent overview of the issues and applications. I am confident that researchers, policy-makers, and practitioners would benefit from this important work.

- Dr. Zamir Iqbal, VP Finance and Chief Financial Officer (CFO) of Islamic Development Bank (IsDB), Jeddah; former Head of World Bank Global Islamic Finance Development Center, Istanbul.

In this digital era, new technology has proven to bring agility, scalability, innovation, and efficiency in operations and means of doing our work. This book argues, persuasively, that the Fintech and Blockchain applications are not only the channels of fusing technology with Islamic finance; it also lays the foundation for new Islamic digital economy, while keeping in view the Maqasid Al-Shariah. This book is a first-of-its-kind contribution to the literature on constructing the Islamic digital economy.

- Dr. Hussain Mohi-ud-Din Qadri, Patron, International Centre of Research in Islamic Economics (ICRIE) Minhaj University, Lahore. 
While the growth of fintech firms has already become a game changer in the conventional financial sector, its application in Islamic economy is still in an incipient stage. The authors of this pioneering work deserve appreciation to not only offer a historical perspective on these exciting developments but also suggest ways to building Islamic digital economy with the use of these tools, especially distributed ledger technology. I would recommend this book to all those who are interested in building a trusted, just and efficient Islamic digital economy.

- Zahid ur Rehman Khokher, Assistant Secretary General of the Islamic Financial Services Board (IFSB), Kuala Lumpur.

The authors hit the mark; blockchain needs to become part and parcel of economics, finance and policy across Muslim-majority countries. It is critical for the leadership to understand what blockchain is and its potential application. Islamic economies need to carefully consider the adoption and the potential institutionalization of blockchain across various facets of their economics. The authors lay the groundwork in this book, and it is a mustread for the broad audience whose desire is to focus on a next generation technology, its adoption and implications.

- Omar Rana, Director of Strategy and Finance at Finalytix, Toronto, and former Chief Investment Officer for a US\$500M private family office in the GCC. 
Dr Hazik Mohamed:

I dedicate this book to my daughters, Aliya and Nadrahuda. And to all their cousins, young and old-Syazwan Hanif, Mohamed Hasif, Abdul Hadi, Haris, Abdul Rahman and Abdul Rahim.

This book contains the shifting trends of the world that you're growing up in. Prepare your contributions for the world to come ... and the Hereafter that awaits.

\section{Hassnian Ali:}

First, to the most devoted and conscientious person in my life, no one else, my late father Ghulam Hussain. 
